\title{
REGULATION OF SLEEPINESS: THE ROLE OF THE AROUSAL SYSTEM
}

\author{
Marija BAKOTIĆ and Biserka RADOŠEVIĆ-VIDAČEK \\ Institute for Medical Research and Occupational Health, Zagreb, Croatia \\ Received in July 2011 \\ CrossChecked in November 2011 \\ Accepted in November 2011
}

\begin{abstract}
Sleepiness is a widespread phenomenon in the busy industrial countries, and many studies have identified its significant negative impacts on individuals and society. Particularly important are the data that associate sleepiness with the risk of accidents at workplace and in transport, pointing to shift workers as the most vulnerable population. It is generally accepted that two basic physiological processes regulate sleepiness: homeostatic and circadian rhythmic processes. Recent research has proposed the third component regulating sleepiness, that is, the wake drive or the arousal system. The role of the arousal system in regulating sleepiness has partly been addressed by the studies of the pathophysiology of insomnia, which is often described as a disorder of hyperarousal. Experimental and correlational studies on the relation between sleepiness and arousal in good sleepers have generally indicated that both physiological and cognitive arousal are related to the standard measures of sleepiness. Taking into account the role of the arousal system in regulating sleepiness widens the possibilities for the management of sleep disorders and could also help in solving the problem of excessive sleepiness at work and the wheel.
\end{abstract}

KEY WORDS: circadian rhythms, insomnia, shift work, sleep homeostasis, wake drive

Sleep research and sleep medicine often define sleepiness as a state reflecting physiological sleep need (1). Other terms used in addition to sleepiness are sleep propensity and sleep tendency. Sleepiness is measured by how long it takes to fall asleep, with tests such as the Multiple Sleep Latency Test (MSLT) (2) and the Maintenance of Wakefulness Test (MWT) (3). Sleepiness is also measured by behaviour such as eye closing, yawning, specific head movement (bobbing), facial expressions, and performance in various psychomotor and cognitive tasks (4). In the subjective domain, measurements include various single- or multi-facetted sleepiness rating scales $(5,6)$ and scales assessing the tendency to fall asleep in various situations (7).

Although sleepiness is a normal physiological state related to sleep need, in certain cases it can be a symptom of a serious disease or condition. In such cases the term pathological or excessive sleepiness is used. The American Academy of Sleep Medicine defines excessive sleepiness as sleepiness that occurs in situations when a person is expected to be awake and alert (8), which interferes with person's daily functioning such as work or school performance, cognitive functioning, mood, and social interaction.

Empirical data indicate that sleepiness significantly contributes to vehicle accidents and that mortality in these accidents is very high, especially in persons younger than 25 years (9-12). Furthermore, sleepiness at the workplace is associated with lower performance and greater risk of occupational accidents and injuries, especially in industrial operations and transportation services $(10,13-15)$. Shift workers run the greatest risk of sleepiness at the workplace because their working time often coincides with the time of the day when humans are biologically programmed to sleep. 
On the other hand, shift workers often sleep at the time when circadian factors promote wakefulness, which can delay the onset and reduce the quality of sleep (16).

Epidemiological studies indicate that excessive sleepiness, that which occurs at least three times a week, affects $4 \%$ to $21 \%$ of the general population, while the prevalence of serious cases, those that occur every day or with extreme manifestations, is around $5 \%$ (17). Excessive sleepiness may be a symptom of sleep disorder, if related to fragmented sleep caused by brief arousals (as in sleep apnoea syndrome or restless legs syndrome), sudden intrusion of REM sleep into wakefulness (as in narcolepsy), irregularity of the sleep-wake cycle (as in delayed sleep phase syndrome), or to no apparent cause (as in idiopathic hypersomnia) (18). Furthermore, excessive sleepiness can be associated with different medical and neurological disorders, or can be a side effect of a drug (8). Finally, excessive sleepiness can appear in otherwise healthy individuals, most often as a result of chronically restricted sleep (insufficient sleep syndrome).

The consequences of a long-term restriction of sleep on daily functioning, especially when sleep is restricted to $4.5 \mathrm{~h}$ to $6.5 \mathrm{~h}$, are still poorly recognised, even though this kind of sleep restriction is the most common. One of the reasons could be the inconsistent results of studies that investigated the cumulative effects of partial sleep restriction on daytime functioning (19-22). Van Dongen et al. (23) emphasised that the lack of evidence about the negative effects of long-term sleep restriction could be owed to methodological limitations such as small sample sizes, few and inadequate measures of neurobehavioral functioning, and no experimental control over sleep that subjects really obtained over 24 hours. Therefore, taking into account methodological limitations of the previous studies, they performed a laboratory study of the consequences of partial sleep restriction on different aspects of neurobehavioral functioning in healthy subjects over 14 consecutive days. The authors found significant cumulative deficits in cognitive performance where sleep was restricted to $4 \mathrm{~h}$ or $6 \mathrm{~h}$ per night. Subjective sleepiness also increased as a function of cumulative sleep loss, but only in the first days of sleep restriction. In the subsequent days, the progressive deterioration in cognitive tasks was not accompanied with further increase in subjective sleepiness. The authors concluded that these results could explain why the phenomenon of chronic sleep deprivation was so widespread - people feel that they have adapted to shorter sleep because they do not feel so much sleepy, although with further sleep restriction their performance continues to deteriorate.

\section{HOMEOSTATIC AND CIRCADIAN COMPONENTS IN THE REGULATION OF SLEEPINESS}

It is widely accepted that sleepiness is regulated by two basic physiological processes, one of which reflects the homeostatic need for sleep and the other body's circadian processes (24). To explore the homeostatic component of sleepiness regulation, researchers measured levels of sleepiness-alertness after manipulating the duration of wake and sleep periods. When wakefulness was prolonged above the usual hours and in conditions of partial sleep restriction, sleep latency measured by the MSLT, significantly dropped $(25,26)$. Carskadon and Dement (20) reported that even a modest partial restriction of sleep accumulated over several nights had progressively reduced sleep latency. Furthermore, studies of partial and total sleep deprivation $(21,26,27)$ reported that subjective ratings of sleepiness increased and performance deteriorated. In general, prolonged wakefulness or restricted sleep inevitably lead to increased sleep propensity (usually measured as the speed of falling asleep) and to increased subjective sleepiness, so that after a certain amount of sleep loss a person will finally fall asleep, even if it were only brief sleep episodes called microsleeps (28). On the other hand, the extension of time in bed beyond the usual seven to eight hours a day in healthy subjects resulted in decreased sleepiness measured with the $\operatorname{MSLT}(29,30)$. It was also found that naps of relatively short duration, usually less than 30 minutes, improved alertness both after a normal and after a restricted overnight sleep $(31,32)$.

Circadian modulation of sleepiness is independent of the homeostatic one and is expressed through cyclic 24-hour variations in sleep propensity. These variations primarily depend on the signals from the circadian pacemaker, which closely interacts with different environmental and social time cues. Earlier studies have already shown that daily variations in subjective sleepiness and objective sleep propensity are closely associated with circadian variations in body temperature. The highest subjective sleepiness is 
around the time of temperature minimum and the lowest around the time of temperature maximum (33). When time cues are present, people usually fall asleep several hours after body temperature starts to decline, while in the experimental conditions without time cues they usually choose to go to sleep around the time when temperature reaches its minimum (34).

Sleep propensity is relatively stable during normal waking hours, except for a possible transient increase in the midafternoon, and it increases rapidly if wakefulness is extended above the usual hours (26, 35 ). Based on the mathematical simulations of the two-process model of sleep regulation, Borbély at al. (25) hypothesised that during habitual waking period circadian pacemaker counteracted homeostatic sleep propensity and preserved the stability of sleep propensity during regular waking hours. This hypothesis was further tested in an experimental study performed by Edgar et al. (36). The authors analysed the effects of lesions of the suprachiasmatic nucleus (SCN), which is a major circadian pacemaker in mammals, on different sleep parameters in squirrel monkeys. The monkeys with SCN lesions lost their major circadian rhythms; they slept shorter but more often and at different times of the day, and their total sleep time was significantly greater than in monkeys without the lesions. The authors concluded that SCN actively promoted wakefulness and opposed the increasing homeostatic sleep propensity during the wake period. The importance of circadian factors to sleepiness regulation was even more emphasised by studies performed according to the protocol of forced desynchrony $(37,38)$. This protocol allows to separately investigate circadian and homeostatic factors as well as their interaction. These studies have shown that in the usual entrained conditions the interaction between circadian and homeostatic factors serves to consolidate both wakefulness and sleep and to facilitate transitions between these states.

\section{AROUSAL COMPONENT IN THE REGULATION OF SLEEPINESS}

Arousal and sleepiness have traditionally been regarded as related constructs, but the role of arousal has never been discussed in the frame of classical models of sleepiness regulation, which are primarily focused on the homeostatic and circadian determinants of sleepiness $(24,39)$. Ideas to add arousal to the classical models of regulation of sleepiness came from several sources. Firstly, studies on insomnia have proposed the hyperarousal hypothesis $(40,41)$ whereby constantly high arousal creates difficulties in falling asleep and maintaining sleep in insomnia patients. They suggest that high arousal is the major reason for lower sleep propensity in insomniacs. Secondly, experimental studies in which the level of arousal was manipulated by physical activity $(42,43)$ showed that heightened physiological activation increased sleep latency in good sleepers. Bonnet and Arand (44) have suggested that standard measures of sleepiness, including the MSLT, always measure a combination of sleep need and the level of arousal, where arousal has both trait and state components. Furthermore, experimental studies in which the subjects were exposed to acute stressors before going to sleep $(45,46)$ showed that increased cognitive arousal resulted in longer sleep latency. Additionally, several correlational studies in healthy subjects showed that sleep propensity and subjective sleepiness were associated with different indices of physiological and cognitive arousal (47-49). In general, these studies have confirmed earlier ideas about the effects of various environmental, behavioural, and cognitive factors on sleepiness $(28,50,51)$, even though they have not directly been associated with arousal.

\section{Chronic insomnia and the hyperarousal hypothesis}

Insomnia has often been described as a disorder of hyperarousal in the sense that level of arousal in insomniacs interferes with the initiation and maintenance of sleep (52). Earlier studies produced surprising findings that insomnia patients, in spite of complaints about fatigue and chronically shorter or poorer night sleep, were not sleepier during the day than normal subjects, as measured with the MSLT (41, $53,54)$. Stepanski (55) found that insomniacs were even more alert than normal sleepers on the MSLT and hypothesised that these results were the consequence of chronic physiological hyperarousal in insomnia patients. Bonnet and Arand (56) used caffeine-induced hyperarousal in healthy subjects as an experimental paradigm to test this hypothesis. In this study, subjects took $400 \mathrm{mg}$ of caffeine three times a day for seven days. Caffeine increased their body metabolism, reduced sleep duration, lowered sleep efficiency, and reduced sleepiness. In the beginning of the study, the subjects reported increased vigour but by the end of the study they complained of daytime fatigue, even though their objective sleepiness, 
measured by the MSLT, remained low. Bonnet and Arand concluded that the discrepancy between subjective fatigue and objective sleepiness, which corresponded to the findings in insomnia patients, could be regarded as the consequence of chronically elevated arousal (in this case due to caffeine intake), and that these results supported the hyperarousal hypothesis. In their review article (40), Bonnet and Arand described insomnia as a 24 -hour disorder in which high levels of physiological arousal were responsible for both disturbed night sleep and daytime symptoms of insomnia.

Many other studies tested the hyperarousal hypothesis of insomnia. Most compared insomnia patients with good sleepers using different indicators of physiological arousal. Earlier findings that insomnia patients had higher body temperature than good sleepers $(57,58)$ have been contested by recent studies $(59,60)$. Other studies found evidence of higher electrodermal activity (61), muscle activity (62), and generally higher metabolic activity in insomnia patients (63). Several studies found a higher heart rate and/or smaller variability of heart rate in insomnia patients compared to healthy persons $(64,65)$, but several recent studies reported insignificant differences in heart activity between these groups $(66,67)$.

Several studies indicated increased secretion of adrenocorticotropic hormone and cortisol in insomnia patients compared to healthy sleepers $(57,68,69)$. In contrast, a recent study (70) showed no significant differences in cortisol levels between insomnia patients and good sleepers between 19:00 and 9:00 hours. In the same study, the insomnia group showed lower melatonin levels, which is in agreement with an earlier study (71). There is evidence about increased norepinephrine secretion in insomnia patients compared to healthy persons (57) and persons suffering from depression (72).

A recent study (73) performed with positron emission tomography revealed that insomnia patients had greater cerebral glucose metabolism than healthy subjects, both awake and during the non-REM sleep. In addition, in the transition from wake to sleep state, insomnia patients had a smaller decline in glucose metabolism in specific brain regions that are considered to promote wakefulness: the ascending reticular activating system, hypothalamus, thalamus, insular cortex, amygdala, and hippocampus. Spectral analyses of the EEG activity showed that, compared to good sleepers, patients with insomnia had a higherfrequency EEG activity (in the beta and gamma bandwidth) both around sleep onset and during the non-REM sleep (74-77). Overall, these studies indicate that chronic insomnia patients are characterised by autonomic and CNS hyperarousal.

Cognitive arousal has also been considered the reason for sleep problems in insomnia. It usually refers to the tendency to excessively worry and ruminate, although it can exist in the form of non-anxious, neutral thoughts. Patients with insomnia are prone to worry about daytime events, especially when they try to fall asleep. When insomnia becomes chronic, worries are very often related to the inability to fall asleep or to the negative effects of insufficient sleep on daytime functioning (78). Insomnia patients seem to blame cognitive arousal as the main cause of their sleep problems $(79,80)$.

Perlis et al. $(76,77)$ suggested the importance of cortical arousal, which occurs as a result of classical conditioning in the pathophysiology of insomnia. The authors assume that increased cortical arousal, which is operationalised as the high-frequency EEG activity, results in enhanced information processing at sleep onset and during the non-REM sleep. Furthermore, enhanced information processing can explain not only sleep difficulties but also different sleep-related phenomena in insomniacs, such as their errors in sleep perception and their tendency to underestimate sleep duration. The authors stress that thinking and worrying before falling asleep, which are often seen in insomniacs, are not primarily responsible for their sleep difficulties, but that they are themselves the consequences of prolonged wakefulness.

\section{Arousing effects of environmental factors}

Audio and visual stimuli such as noise and light have arousing effects on human physiology and can affect the level of sleepiness. The effects of noise were mostly investigated in relation to sleep continuity and sleep structure rather than in relation to sleepiness (81-84). These studies showed that exposure to noise during sleep (e.g. traffic noise) led to increased autonomic and cortical arousal that could cause frequent awakenings and affect sleep depth. The effects of listening to the radio were explored in a study performed by Reyner and Horne (85); subjects were listening to the radio while driving in a car simulator after a night of restricted sleep. Listening to the radio did not decrease the rate of road accidents in the simulator and there were no significant changes in the EEG measure of sleepiness, although the subjects did report feeling less sleepy than subjects 
who did not listen to the radio. Bonnet and Arand (86) explored the effects of listening to favourite music on the ability to fall asleep measured with the MSLT and the ability to maintain wakefulness measured with the MWT. As expected, sleep latencies were longer in both tests when the subjects were listening to the music, but this effect was much smaller after the subjects were deprived of sleep. In addition, music was associated with higher heart rate, which is in accordance with the hypothesis that music increases sleep latency by increasing physiological arousal.

Light, as another environmental factor, primarily affects the circadian rhythms, but its physiological and behavioural effects have also been noted. Factors such as light intensity, timing, and wavelength determine how light affects alertness. Exposure to bright light $(\geq 1000$ lx) during evening or night hours increases body temperature, suppresses melatonin secretion, and enhances alertness and performance (87-90). Treatment with bright light is often recommended to workers who want to improve their adaptation to work at night, but also to re-adapt to day life (91-93). More recent studies (94-96) showed that positive effects of bright light on sleepiness and performance occurred both during night-time or daytime hours. In a study by Cajochen et al. (89) subjects were exposed to light in a range between $3 \mathrm{~lx}$ and $9100 \mathrm{~lx}$ for $6.5 \mathrm{~h}$ during early biological night (before body temperature minimum), and the effects of light were measured with three indices of alertness (reduction of subjective sleepiness, EEG activity in the theta-alpha frequency, and the incidence of slow eye movements). The relationship between the intensity of light and all three indices of alertness was nonlinear; exposure to lower intensities, even within the range of typical room light ( $90 \mathrm{~lx}$ to $180 \mathrm{~lx}$ ), had a relatively great alerting effect. After reaching a certain point, further increases in light intensity did not produce additional effect. Recent studies of the alerting effects of different light wavelengths (97-99) consistently showed that short wavelengths $(\leq 470 \mathrm{~nm})$, such as blue light, had the greatest alerting impact.

\section{Arousing effects of behavioural and cognitive factors}

Sleep is basically a behavioural state, so it is not surprising that behavioural factors such as posture and physical activity have been suggested as powerful determinants of sleep propensity $(50,51)$. It is common knowledge that lying down will facilitate sleep onset, while standing will help us to remain awake even if we have not slept for a longer period. The effects of body posture on sleep tendency can be associated with different levels of autonomic nervous system activity that accompany changes in posture; sympathetic activity is higher while sitting compared to lying and while standing compared to sitting (100).

Bonnet and Arand (42) experimentally examined the influence of physical activity on sleep propensity. The authors compared sleep latencies using the MSLT in two different situations: after watching TV and after a short walk. After a short walk, sleep latency was significantly longer and the heart rate, which was used as a measure of physiological arousal, was significantly higher. The authors concluded that the activation of the sympathetic nervous system, which was induced by walking and measured with the heart rate, masked the basic level of sleepiness and resulted in significantly longer sleep latency. The same conclusion can be drawn from another Bonnet and Arand's (43) study in which they measured the ability to maintain wakefulness during sleep deprivation using an adapted version of the MWT. The level of physiological arousal was manipulated by varying the level of physical activity at the beginning of the stage 1 sleep. The ability to maintain wakefulness varied with the level of physical activity in a way that sleep latency observed was longer as physical activity was more demanding. This study established a negative correlation between sleep latency and the interval between heart beats; the subjects could maintain their wakefulness for longer when their heart beat intervals were shorter.

Motivational factors were also found to have a significant impact on sleep propensity. For example, if the standard instruction "try to fall asleep" in the MSLT were changed to "try to stay awake", sleep latency would significantly increase $(44,101)$. Comparison of the relative contribution of the instruction to stay awake and changes in posture to sleep latency (44) showed greater effect of the instruction. The change in instruction increased sleep latency by 10 minutes compared to the standard MSLT, while the posture change increased sleep latency by six minutes. The authors also found that motivation and posture had additive effects and concluded that different results that had been usually obtained with the MSLT and the MWT could be explained by differences in the sources of arousal in these two sleepiness tests. 
Motivation is believed to be one the most influential determinants of our effectiveness under conditions of sleep deprivation. Negative consequences of sleep deprivation on task performance are usually best seen when performing long monotonous tasks. On the other hand, an additional effort that a person invests while performing an interesting and stimulating task can mask the negative effects of sleepiness on a performance, both in experimental settings and real life (102). Night work primarily relies on the motivation and decision to stay awake during the hours when both homeostatic and circadian factors promote sleepiness. Furthermore, well known "post-lunch" dip often passes without noticing mostly because of the alerting effects related to stimulant activities. In one study which explored the possible exogenous factors that can influence circadian-driven sleepiness in the early afternoon (103), subjects who were engaged in interesting activities reported lower sleepiness and performed better in a time reaction task compared to subjects who were engaged in boring activities. Higher heart rate was noted in the former group, implying that the interesting experimental setting increased the level of autonomic arousal.

The concept of arousal can be useful in explaining the mechanisms through which stressful events and daily hassles influence sleep. From everyday experience we know that excessive thinking and worrying before going to sleep, which are common reactions to stress exposure, are associated with shorter and poorer sleep and difficulties in falling asleep. Stress is considered to be the most frequent cause of transient insomnia, although the number of systematic studies on this topic is still relatively scarce, mostly due to the transitory and unpredictable nature of the stressful events and additionally because of great individual variations in subjective interpretation of the events that are considered stressful (104).

In several experimental studies the effect of cognitive activation (acute stress) on sleep latency was examined either before going to sleep or during daytime. One of the earlier studies was performed by Gross and Borkovec (45), who found significantly longer sleep latency in a group of subjects who were told that they would have to deliver a speech upon waking-up compared to a control group who received no instructions before bedtime. However, the results obtained for heart and electrodermal activity did not confirm the authors' hypothesis that autonomic activation contributed to longer sleep latency. Hall et al. (105) performed a study with a similar research design, but they measured heart activity before and during experimental manipulation and additionally during the whole night. The analysis showed that the level of sympathetic activity during non-REM sleep in subjects who were told that they would have to deliver a speech was higher than in subjects who were told that they would read magazines after waking-up. A higher level of sympathetic activity was associated with lower sleep efficiency and less delta activity, implying that sustained autonomic arousal is one of the pathways through which stress affects sleep.

De Valck et al. (45) examined the effects of cognitive activation on daytime sleep latency after partial sleep deprivation. In the experimental situation, the participants were asked to give an interview in front of a TV camera about their enrolment in the study. Sleep latency was significantly longer in the experimental situation compared to control, in which no such activity was required. Heart rate, which was used as a measure of the level of activation, was higher in the experimental situation, although it did not correlate with sleep latency. On the other hand, in a study by Tang and Harvey (106), which also examined the effect of the level of arousal on sleep latency observed, subjective latency was in contradiction to objective latency during an afternoon nap. Subjects who expected the interview reported longer sleep latency than those who did not, while the difference in the objective measure of sleep latency obtained by actigraphy was in the opposite direction.

\section{Arousal in the model of sleepiness proposed by Cluydts and De Valck}

Cluydts and De Valck $(107,108)$ recently proposed a model that extends beyond traditional models of sleepiness regulation. According to this model, the level of sleepiness in a certain moment depends on the relation between the level of the sleep drive (sleep need) and the level of the wake drive, which the authors equate with the level of arousal. Furthermore, Cluydts and De Valck assume that both drives have their state and trait components. State components are generally related to momentary variations in the sleep drive and variations of arousal due to situational factors. Trait components refer to the level of the sleep drive and arousal that are relatively stable and typical for an individual. According to this model, high sleepiness can be the result of habitual or acutely high sleep drive, habitually or acutely low arousal or the result of their combination. This model supports the idea that sleepiness is a multidimensional construct 
and that each measure of sleepiness can be more or less suitable for the measurement of certain aspects of this phenomenon. Bakotic (109) tested this model in a study of the effects of different levels of experimentally induced physiological and cognitive arousal on daytime sleepiness after partial sleep deprivation. The study has shown that even a small increase in physiological and cognitive arousal affects daytime sleepiness in good sleepers and has confirmed the importance of situational arousal in the regulation of daytime sleepiness. However, it has not confirmed the importance of the trait arousal, operationalised with electrodermal lability, and trait sleepiness, measured with the Epworth Sleepiness Scale, for the level of daytime sleepiness. Further studies in the frame of this model are needed to evaluate the concept and measurement of sleepiness and the mechanisms of its regulation.

\section{PRACTICAL IMPLICATONS}

Taking arousal as the third component in the regulation of sleepiness, in addition to circadian and homeostatic factors, widens the possibilities for the management of sleep problems on the one hand, and for the maintenance of alertness in different work settings and transportation on the other. In clinical and counselling psychology, different behavioural and cognitive strategies have already been used to treat chronic insomnia $(110,111)$. For example, patients are taught relaxation techniques to decrease the level of somatic arousal and cognitive techniques to stop intrusive thoughts and worries while trying to fall asleep. Avoiding stimulants and activities that can increase arousal before going to sleep, such as caffeine, nicotine, and exercise close to bedtime, are already among the standard recommendations for better sleep for either insomnia patients or good sleepers (112). These are being disseminated through public health education aimed at adolescents $(113,114)$.

Further studies of the arousal component of sleepiness could be useful for work psychology. These studies could show the way to strategies to maintain alertness and performance of workers in automated industries that depend on vigilant monitoring, and of workers who usually spend a lot of time in sedentary activities such as doing a computer work, office work, and driving (115). These strategies could take into account alerting effects of different environmental stimuli and cognitive-behavioural factors such as physical activity and motivation that affect the level of sleepiness and performance.

A special population who may particularly benefit from strategies against sleepiness at the work place are shift workers. Some of the most serious environmental disasters such as the oil spill of the Exxon Valdez (116) and the explosion of the nuclear reactor in Chernobyl (117) have been associated with the combined effects of circadian factors and sleep deprivation of the workers who made critical decisions. In addition, many shift workers experience problems with sleeping during the day, in spite of increased sleep need after a night shift, which is usually attributed to the alerting effects of the circadian factors and environmental stimuli such as increased daytime noise. However, problems with falling asleep and maintaining daytime sleep in shift workers could partly be the consequence of psychosocial stress, which could interfere with sleep through somatic and cognitive arousal. A recent study by Morishima et al. (118) explored the role of autonomic activity in subjects who felt sleepy but could not fall asleep in relaxed conditions during daytime. They found that problems with sleeping during the daytime happened to persons whose autonomic nervous activity did not show the expected decrease in the sympathetic and increase in parasympathetic activity in conditions which were convenient for relaxation and sleeping. Further studies in this area should use various measures of arousal and focus on the effects of psychosocial stress on daytime sleepiness.

\section{CONCLUSION}

The importance of the arousal system in the regulation of sleepiness has been recognised by insomnia research, and scientific knowledge about the relation between arousal and sleepiness has already been used in practice. However, some aspects of this relation still need to be explored, such as the interaction between sleep promoting factors and arousal in regulation of sleep tendency. Studies should also address different situational factors which, according to model by Cluydts and De Valck, modify the basal levels of arousal and sleepiness, as well as the underlying physiological mechanisms. Further studies could also help better understand the effects of stress on sleep and the pathways of this influence. In this sense, it would be important to explore whether subtle changes in the arousal level, which probably 
accompany our exposure to daily stressors, could also affect subjective sleepiness and the ability to fall asleep.

\section{Acknowledgement}

This research was supported by the Croatian Ministry of Science, Education and Sports (grant number 022-0222411-2659).

\section{REFERENCES}

1. Carskadon MA, Dement WC. The multiple sleep latency test: what does it measure? Sleep 1982;5:S67-S72.

2. Carskadon MA, Dement WC, Mitler MM, Roth T, Westbrook PR, Keenan S. Guidelines for the Multiple Sleep Latency Test (MSLT), a standard measure of sleepiness. Sleep 1986;9:51924.

3. Sangal R B, Thomas L, Mitler MM. Maintenance of wakefulness test and multiple sleep latency test. Measurement of different abilities in patients with sleep disorders. Chest 1992;101:898-902.

4. Dinges DF, Powell JW. Microcomputer analyses of performance on a portable, simple visual RT task during sustained operations. Behav Res Meth Ins C 1985;17:6525.

5. Åkerstedt T, Gillberg M. Subjective and objective sleepiness in the active individual. Int J Neurosci 1990;52:29-37.

6. Hoddes E, Zarcone V, Smythe HR, Phillips R, Dement WC Quantification of sleepiness, a new approach. Psychophysiology 1973;10:431-6.

7. Johns MW. A new method for measuring sleepiness, the Epworth Sleepiness Scale. Sleep 1991;14:540-5.

8. Littner MR, Kushida C, Wise M, Davila DG, Morgenthaler T, Lee-Chiong T, Hirshkowitz M, Loube DL, Bailey D, Berry RB, Kapen S, Kramer M. Practice parameters for clinical use of the Multiple Sleep Latency Test and the Maintenance of Wakefulness Test. Standards of practice committee of the American Academy of Sleep Medicine. Sleep 2005;28:11321.

9. Dinges DF. An overview of sleepiness and accidents. J Sleep Res 1997;4(Suppl 2):4-14

10. Garbarino S, Nobili L, Beelke M, De Carli F, Ferrillo F. The contributing role of sleepiness in highway vehicle accidents. Sleep 2001;24:203-6.

11. Philip P, Sagaspe P, Lagarde E, Leger D, Ohayon M, Bioulac B, Boussuge J, Taillard J. Sleep disorders and accidental risk in a large group of regular registered highway drivers. Sleep Med 2010;11:973-9.

12. Zucconi M. Article reviewed: Distribution of road accidents in policemen on shift-work on Italian highways: the contributing role of sleepiness. Sleep Med 2001;2:561-3.

13. Åkerstedt T, Fredlund P, Gillberg M, Jansson B. A prospective study of fatal occupational accidents - relationship to sleeping difficulties and occupational factors. J Sleep Res 2002;11:6971.

14. Lauber JK, Kayten PJ. Sleepiness, circadian dysrhythmia, and fatigue in transportation system accidents. Sleep 1998;11:503-12.
15. Mitler MM, Carskadon MA, Czeisier CA, Dement WC, Dinges DF, Graeber RS. Catastrophes, sleep, and public policy: consensus report. Sleep 1988;11:100-9.

16. Åkerstedt T. Shift work and disturbed sleep/wakefulness. Sleep Med Rev 1998;2:117-28.

17. Ohayon MM. From wakefulness to excessive sleepiness, what we know and still need to know. Sleep Med Rev 2008;12:12941.

18. El-Ad B, Korczyn AD. Disorders of excessive daytime sleepiness - an update. J Neurol Sci 1998;153:192-202.

19. Blagrove M, Alexander C, Horne JA. The effects of chronic sleep reduction on the performance of cognitive tasks sensitive to sleep deprivation. Appl Cogn Psychol 1995;9:21-40.

20. Carskadon MA, Dement WC. Cumulative effects of sleep restriction on daytime sleepiness. Psychophysiology 1981;18:107-13

21. Dinges DF, Pack F, Williams K, Gillen KA., Powell JW, Ott GE, Aptowicz C, Pack AI. Cumulative sleepiness, mood disturbance, and psychomotor vigilance performance decrements during a week of sleep restricted to $4-5$ hours per night. Sleep 1997;20:267-77.

22. Horne JA, Wilkinson S. Chronic sleep reduction: daytime vigilance performance and EEG measures of sleepiness, with particular reference to "practice" effects. Psychophysiology 1985;22:69-78.

23. Van Dongen HPA, Maislin G, Mullington JM, Dinges DF. The cumulative cost of additional wakefulness, dose-response effects on neurobehavioral functions and sleep physiology from chronic sleep restriction and total sleep deprivation. Sleep 2003;26:117-26.

24. Borbély AA. A two process model of sleep regulation. Hum Neurobiol 1982;1:195-204.

25. Borbély AA, Achermann P, Trachsel L, Tobler I. Sleep initiation and initial sleep intensity: interactions of homeostatic and circadian mechanisms. J Biol Rhythms 1989;4:37-48.

26. Carskadon MA, Dement WC. Effects of total sleep loss on sleep tendency. Percept Mot Skills 1979;48:495-506.

27. Babkoff H, Caspy T, Mikulincer M. Subjective sleepiness ratings, the effects of sleep deprivation, circadian rhythmicity and cognitive performance. Sleep 1991;14:534-9.

28. Dingens DF. The nature of sleepiness: Nature, causes, and consequences. In: Stunkard AJ, Baum A, editors. Perspectives in behavioral medicine. Eating, sleeping, and sex. New Jersey: Lawrence Erlbaum Associates, Inc.; 1989. p. 147-79.

29. Roehrs T, Shore E, Papineau K, Rosenthal L, Roth T. A twoweek sleep extension in sleepy normals. Sleep 1996;19:57682

30. Roehrs T, Timms V, Zwyghuizen-Doorenbos A, Roth T. Sleep extension in sleepy and alert normals. Sleep 1989;12:44957.

31. Gillberg M, Kecklund G, Axelsson J, Åkerstedt T. The effects of a short daytime nap after restricted night sleep. Sleep 1996;19:570-5.

32. Hayashi M, Masuda A, Hori T. The alerting effects of caffeine, bright light and face washing after a short daytime nap. Clin Neurophysiol 2003;114:2268-78.

33. Åkerstedt T, Fröberg JE. Psychophysiological circadian rhythms in women during $72 \mathrm{~h}$ of sleep deprivation. Waking Sleeping 1977;1:387-94.

34. Zulley J, Wever R, Aschoff J. The dependence of onset and duration of sleep on the circadian rhythm of rectal temperature. Eur J Physiol 1981;4:314-8. 
35. Carskadon MA, Dement WC. Multiple sleep latency tests during the constant routine. Sleep 1992;15:396-9.

36. Edgar DM, Dement WC, Fuller CA. Effect of SCN lesions on sleep in squirrel monkeys: Evidence for opponent processes in sleep-wake regulation. J Neurosci 1993;13:106579.

37. Dijk D-J, Czeisler CA. Paradoxical timing of the circadian rhythm of sleep propensity serves to consolidate sleep and wakefulness in humans. Neurosci Lett 1994;166:63-8.

38. Dijk D-J, Czeisler CA. Contribution of the circadian pacemaker and the sleep homeostat to sleep propensity, sleep structure, electroencephalographic slow waves, and sleep spindle activity in humans. J Neurosci 1995;15:3526-38.

39. Folkard S, Åkerstedt T. Towards a model for the prediction of alertness and/or fatigue on different sleep/wake schedules. In: Oginski A, Pokorski J, Rutenfranz J, editors. Contemporary advances in shiftwork research. Krakóv: Medical Academy; 1987. p. 231-40.

40. Bonnet MH, Arand DL. Hyperarousal and insomnia. Sleep Med Rev 1997;1:97-108.

41. Stepanski E, Lamphere J, Badia P, Zorick F, Roth T. Sleep fragmentation and daytime sleepiness. Sleep 1984;7:18-26.

42. Bonnet MH, Arand DL. Sleepiness as measured by modified Multiple Sleep Latency Testing varies as a function of preceding activity. Sleep 1998;21:477-83.

43. Bonnet MH, Arand DL. Level of arousal and the ability to maintain wakefulness. J Sleep Res 1999;8:247-54.

44. Bonnet MH, Arand DL. Arousal components which differentiate the MWT from the MSLT. Sleep 2001;24:4417.

45. Gross RT, Borkovec TD. Effects of a cognitive intrusion manipulation on the sleep onset latency of good sleepers. Behav Ther 1982;13:112-6.

46. De Valck, E, Cluydts R, Pirrera S. Effect of cognitive arousal on sleep latency, somatic and cortical arousal following partial sleep deprivation. J Sleep Res 2004;13:295-304.

47. Johns MW, Thornton C, Dore C. Heart rate and sleep latency in young men. J Psychosom Med 1976;20:549-53.

48. Kronholm E, Hyyppä MT, Alanen E, Halonen JP, Partinen M. What does the Multiple Sleep Latency Test measure in a community sample? Sleep 1995;18:827-35.

49. Pressman MR, Fry JM. Relationship of autonomic nervous system activity to daytime sleepiness and prior sleep. Sleep 1989;12:239-45

50. Johns MW. Rethinking the assessment of sleepiness. Sleep Med Rev 1998;2:3-15.

51. Webb WB. An objective behavioral model of sleep. Sleep 1988;11:488-96.

52. Perlis ML, Smith MT, Pigeon WR. Etiology and pathophysiology of insomnia. In: Kryger NH, Roth T, Dement WC, editors. Principles and practice of sleep medicine. Philadelphia: Sanders Co; 2000. p. 714-25.

53. Seidel WF, Ball S, Cohen S, Patterson N, Yost D, Dement WC. Daytime alertness in relation to mood, performance, and nocturnal sleep in chronic insomniacs and noncomplaining sleepers. Sleep 1984;7:230-8.

54. Sugarman IL, Stern JA, Walsh JK. Daytime alertness in subjective and objective insomnia: some preliminary findings. Biol Psychiatry 1985;20:741-50.

55. Stepanski E, Zorick F, Roehrs T, Young D, Roth T. Daytime alertness in patients with chronic insomnia compared with asymptomatic control subjects. Sleep 1988;11:54-60.
56. Bonnet MH, Arand DL. Caffeine use as a model of acute and chronic insomnia. Sleep 1992;15:526-36.

57. Adams K, Tomeny M, Oswald I. Physiological and psychological differences between good and poor sleepers. J Psychiatr Res 1986;20:301-16.

58. Monroe LJ. Psychological and physiological differences between good and poor sleepers. J Abnorm Psychol 1967;72:255-64

59. Campbell SS, Murphy PJ. Relationship between sleep and body temperature in middle-aged and older subjects. J Am Geriatr Soc 1998;46:458-62.

60. Rosa R, Bonnet M. Reported chronic insomnia is independent of poor sleep as measured by electroencephalography. Psychosom Med 2000;62:474-82.

61. Broman JE, Hetta J. Electrodermal activity in patients with persistent insomnia. J Sleep Res 1994;3:165-70.

62. Haynes SN, Follingstad DR, McGowen WT. Insomnia: sleep patterns and anxiety level. J Psychosom Res 1974;18:6974.

63. Bonnet MH, Arand DL. 24-hour metabolic rate in insomniacs and matched normal sleepers. Sleep 1995;18:581-8.

64. Bonnet MH, Arand DL. Heart rate variability in insomniacs and matched normal sleepers. Psychosom Med 1998;60:6105.

65. Stepanski E, Glinn M, Zorick FJ, Roehrs T, Roth T. Heart rate changes in chronic insomnia. Stress Med 1994;10:261-6.

66. Fang SC, Huang CJ, Yang TT, Tsai PS. Heart rate variability and daytime functioning in insomniacs and normal sleepers: preliminary results. J Psychosom Res 2008;65:23-30.

67. Varkevisser M, Kerkhof GA. Chronic insomnia and performance in a 24-h constant routine study. J Sleep Res 2005; 14:49-59.

68. Rodenbeck A, Huether G, Rüther E, Hajak G. Interactions between evening andnocturnal cortisol secretion and sleep parameters in patients with severe chronic primary insomnia. Neurosci Lett 2002;324:159-63.

69. Vgontzas AN, Bixler EO, Lin HM, Prolo P, Mastorakos G, Vela-Bueno A, Kales A, Chrousos GP. Chronic insomnia is associated with nyctohemeral activation of the hypothalamicpituitary-adrenal axis, clinical implications. J Clin Endocrinol Metab 2001;86:3787-94.

70. Riemann D, Klein T, Rodenbeck A, Feigea B, Hornya A, Hummela R, Weskea G, Al-Shajlawia A, Voderholzera U. Nocturnal cortisol and melatonin secretion in primary insomnia. Psychiatry Res 2002;113:17-27.

71. Rodenbeck A, Huether G, Rüther E, Hajak G. Nocturnal melatonin secretion and its modification by treatment in patients with sleep disorders. Adv Exp Med Biol 1999;467:8993.

72. Irwin M, Clark C, Kennedy B, Gillin JC, Ziegler M. Nocturnal catecholamines and immune function in insomniacs, depressed patients, and control subjects. Brain Behav Immun 2003; $17: 365-72$

73. Nofzinger EA, Buysse DJ, Germain A, Price JC, Miewald JM, Kupfer DJ. Functional neuroimaging evidence for hyperarousal in insomnia. Am J Psychiatry 2004;161:21268.

74. Lamarche $\mathrm{CH}$, Ogilvie RD. Electrophysiological changes during the sleep onset period of psychophysiological insomniacs, psychiatric insomniacs, and normal sleepers. Sleep 1997;20:724-33. 
75. Mercia H, Blois R, Gaillard JM. Spectral characteristics of sleep EEG in chronic insomnia. Eur J Neurosci 1998;10:182634.

76. Perlis ML, Giles DE, Mendelson WB, Bootzin RR, Wyatt JK Psychophysiological insomnia: the behavioral model and a neurocognitive perspective. J Sleep Res 1997;6:179-88.

77. Perlis ML, Smith MT, Andrews PJ, Orff H, Giles DE. Beta/ Gamma EEG activity in patients with primary and secondary insomnia and good sleeper controls. Sleep 2001;24:110-7.

78. Harvey AG. Pre-sleep cognitive activity: A comparison of sleep-onset insomniacs and good sleepers. Br J Clin Psychol 2000;39:275-86.

79. Lichstein KL, Rosentahl TL. Insomniacs' perceptions of cognitive versus somatic determinants of sleep disturbance. J Abnorm Psychol 1980;89:105-7.

80. Espie CA, Brooks DN, Lindsay WR. An evaluation of tailored psycological treatment of insomnia. J Behav Ther Exp Psychiatry 1989;20:143-53.

81. Carter NL, Hunyor SN, Crawford G, Kelly D, Smith AJ. Environmental noise and sleep: a study of arousals, cardiac arrhythmia and urinary catecholamines. Sleep 1994;17:298307.

82. Carter N, Henderson R, Lal S, Hart M, Booth S, Hunyor S Cardiovascular and autonomic response to environmental noise during sleep in night shift workers. Sleep 2002;25:45764.

83. Griefahn B, Bröde P, Marks A, Basner M. Autonomic arousals related to traffic noise during sleep. Sleep 2008;31:569-77.

84. Saremi M, Grenèchea J, Bonnefonda A, Rohmera O, Eschenlauera A, Tassia, P. Effects of nocturnal railway noise on sleep fragmentation in young and middle-aged subjects as a function of type of train and sound level. Int J Psychophysiol 2008;70;184-91.

85. Reyner LA, Horne JA. Evaluation of "in-car" countermeasures to sleepiness: Cold air and radio. Sleep 1998;21:46-50.

86. Bonnet MH, Arand DL. The impact of music upon sleep tendency as measured by the Multiple Sleep Latency Test and Maintenance of Wakefulness Test. Physiol Behav 2000;71:48592.

87. Badia P, Myersa B, Boeckera M, Culpeppera J, Harshb JR. Bright light effects on body temperature, alertness, EEG and behavior. Physiol Behav 1991;50:583-8.

88. Bunnell DE, Treiber SP, Phillips NH, Berger RJ. Effects of evening bright light exposure on melatonin, body temperature and sleep. J Sleep Res 1992;1:17-23.

89. Cajochen C, Zeitzer JM, Czeislerm CA, Dijk DJ. Doseresponse relationship for light intensity and ocular and electroencephalographic correlates of human alertness. Behav Brain Res 2000;115:75-83.

90. Lewy AJ, Wehr TA, Goodwin FK, Newsome DA, Markey SP. Light suppresses melatonin secretion in humans. Science 1980;210:1267-9.

91. Bjorvatn B, Kecklund G, Åkerstedt T. Bright light treatment used for adaptation to night work and re-adaptation back to day life. A field study at an oil platform in the North Sea. J Sleep Res 1999;8:105-12.

92. Czeisler CA, Dijk D-J. Use of bright light to treat maladaptation to night shift work and circadian rhythm sleep disorders. J Sleep Res 1995;4(Suppl 2):70-3.

93. Sadeghniiat-Haghighi K, Yazdi Z, Jahanihashemi H, Aminian $\mathrm{O}$. The effect of bright light on sleepiness among rapid- rotating 12-hour shift workers. Scand J Work Environ Health 2011;37:77-9.

94. Phipps-Nelson J, Redman JR, Dijk D-J, Rajaratnam SMW. Daytime exposure to bright light, as compared to dim light, decreases sleepiness and improves psychomotor vigilance performance. Sleeep 2003;26:695-700.

95. Ruger M, Gordijn MCM, Beersma DGM, de Vries B, Daan S. Time-of-day-dependent effects of bright light exposure on human psychophysiology: comparison of daytime and nighttime exposure. Am J Physiol Regul Integr Comp Physiol 2006;290:R1413-20.

96. Vandewalle G, Balteau E, Phillips C, Degueldre C, Moreau V, Sterpenich V, Albouy G, Darsaud A, Desseilles M, DangVu TT, Peigneux P, Luxen A, Dijk D-J, Maquet P. Daytime light exposure dynamically enhances brain responses. Curr Biol 2006;16:1616-21.

97. Cajochen C, Münch M, Kobialka S, Kräuchi K, Steiner R, Oelhafen P, Orgül S, Wirz-Justice A. High sensitivity of human melatonin, alertness, thermoregulation, and heart rate to short wavelength light. J Clin Endocrinol 2005;90:13116.

98. Lockley SW, Evans EE, Scheer FAJL, Brainard GC, Czeisler CA, Aeschbach D. Short-wavelength sensitivity for the direct effects of light on alertness, vigilance, and the waking electroencephalogram in humans. Sleep 2006;29:161-8.

99. Revell VL, Arendt J, Fogg LF, Skene DJ. Alerting effects of light are sensitive to very short wavelengths. Neusrosci Lett 2006;399:96-100.

100. Lindqvist A, Jalonen J, Parviainen P, Antila K, Laitinen LA. Effect of posture on spontaneous and thermally stimulated cardiovascular oscillations. Cardiovasc Res 1989;24:37380.

101. Hartse KM, Roth T, Zorick FJ. Daytime sleepiness and daytime wakefulness: the effect of instruction. Sleep 1982;5(Suppl 2):S107-18.

102. Harrison Y, Horne JA. The impact of sleep deprivation on decision making: a review. J Exp Psychol Appl 2000;6:23649.

103. Mavjee V, Horne JA. Boredom effects on sleepiness/alertness in the early afternoon vs. early evening and interactions with warm ambient temperature. Br J Psychol 1994;85:317-33.

104. Roehrs T. Stress and insomnia. In: Bolis L, Licinio J, edtors. Stress and the nervous system. Geneva: World Health Organisation Advisory Committee on Health Research; 1998. p. 63-76.

105. Hall M, Vasko R, Buysse D, Ombao H, Chen Q, Cashmere JD, Kupfer D, Thayer JF. Acute stress affects heart rate variability during sleep. Psychosom Med 2004;66:56-62.

106. Tang NKY, Harvey AG. Effects of cognitive arousal and physiological arousal on sleep perception. Sleep 2004;27:6978.

107. Cluydts R, De Valck E, Verstraeten E, Theys P. Daytime sleepiness and its evaluation. Sleep Med Rev 2002;6:83-96.

108. De Valck E, Cluydts R. Sleepiness as a state-trait phenomenon, comprising both a sleep drive and a wake drive. Med Hypotheses 2003;60:509-12.

109. Bakotić M. Razlike u razini aktivacije i dnevna pospanost nakon djelomične deprivacije spavanja [Differences in the level of activation and daytime sleepiness after partial sleep deprivation; in Croatian] [PhD thesis]. Zagreb: Faculty of Philosophy, University of Zagreb; 2011. 
110. Morin CM. Cognitive-behavioral approaches to the treatment of insomnia. J Clin Psychiatry 2004;65(Suppl 16):33-40.

111. Yang C-M, Spielman AJ. The role of behavioural treatment in the management of insomnia. Dis Manage Health Outcomes 1999;5:209-24.

112. Stepanski EJ, Wyatt JK. Use of sleep hygiene in the treatment of insomnia. Sleep Med Rev 2003;7:215-25.

113. Bakotić M, Radošević-Vidaček B, Košćec A. Experimental study of effectiveness of educational leaflet. Croat Med J 2009;50:174-81.

114. Fisher F, Radošević-Vidaček B, Košćec A, Teixeira L, Moreno $\mathrm{C}$, Lowden A. Internal and external time conflicts in adolescents: sleep characterstics and interventions. Mind Brain Educ 2008;2:17-23.

115. Caldwell JA, Lynn Caldwell J, Schmidt RM. Alertness management strategies for operational contexts. Sleep Med Rev 2008;12:257-73.
116. NTSB. Grounding of the US tankship Exxon Valdez on Bligh Reef, Prince William Sound near Valdez, Alaska, March 24, 1989. National Transportation Safety Board. Maritime Accident Report, NTSB/MAR-90/04, 1990.

117. Mitler MM, Carskadon MA, Czeisler CA, Dement WC, Dinges DF, Graeber RC. Catastrophes, sleep, and public policy: consensus report. Sleep 1988;11:100-9.

118. Morishima H, Sugiyama E, Matsushita M, Uruha S, Ito S, Abe Y, Nishitani M, Watanabe T, Suganuma N, Yamamura S, Yanagi K, Shigedo Y, Kumano-Go T, Adachi H, Mikami A, Sugita Y, Takeda M. How is autonomic nervous system activity in subjects who are sleepy but are unable to sleep in the daytime? Sleep Biol Rhythms 2009;7:23-30. 


\section{Sažetak}

\section{ULOGA AKTIVACIJSKOGA SUSTAVA U REGULACIJI POSPANOSTI}

Pospanost je raširena pojava u industrijskim zemljama i njeni negativni učinci na pojedince i društvo ustanovljeni su u brojnim istraživanjima. Od posebne su važnosti podaci koji upućuju na to da pospanost povećava vjerojatnost nesreća na radu i u prometu, što je naročito izraženo u populaciji smjenskih radnika. Općenito je prihvaćeno da pospanost reguliraju dva temeljna fiziološka procesa, od koji se jedan odnosi na homeostazu spavanja, a drugi na cirkadijurno funkcioniranje organizma. Nedavno objavljeni modeli pospanosti predložili su uključivanje nagona za budnošću, odnosno razine aktivacije, kao trećeg čimbenika koji sudjeluje u regulaciji pospanosti. Ideje o važnosti aktivacijskog sustava u regulaciji pospanosti dijelom su proizašle iz ispitivanja patofiziologije nesanice koja se često opisuje kao poremećaj pretjerane pobuđenosti. Eksperimentalna i korelacijska istraživanja odnosa između pospanosti i aktivacije kod dobrih spavača općenito su pokazala kako su fiziološka i kognitivna aktivacija povezane sa standardnim mjerama pospanosti. Uvažavanje aktivacijskog sustava u regulaciji pospanosti otvara šire mogućnosti za rješavanje problema sa spavanjem te bi također moglo pomoći u rješavanju problema pretjerane pospanosti u različitim radnim okruženjima i prometu.

KLJUČNE RIJEČI: cirkadijurni ritmovi, homeostaza spavanja, nagon za budnošću, nesanica, smjenski $\mathrm{rad}$

\section{CORRESPONDING AUTHOR:}

Biserka Radošević-Vidaček, $\mathrm{PhD}$

Institute for Medical Research and Occupational Health

Ksaverska cesta 2, HR-10000 Zagreb, Croatia

E-mail: bvidacek@imi.hr 